\title{
Ready to Hire a Freelance Journalist: The Change in Estonian Newsrooms' Willingness to Outsource Journalistic Content Production
}

\author{
Marju Himma-Kadakas \\ (D) 0000-0001-9441-7162 \\ Karlstad University, Sweden
}

Mirjam Mõttus

University of Tartu, Estonia

\begin{abstract}
This paper explores the change in Estonian media organizations' readiness to cooperate with freelance journalists. The interviews with editors of newsrooms of magazines, newspapers, and radio and television broadcasters were conducted in 2014 and 2019. The findings were additionally tested in the conditions of the Covid-19 crisis in 2020. The paper outlines how over the five years the editors have not only changed their perception of who freelance journalists are but how they express the readiness to outsource content from journalistic entrepreneurs. We conclude that the Estonian media market shows signs of adopting diverse collaborative forms that diverge from the journalistic field. The freelancers' concept has changed, indicating integration of journalistic and entrepreneurial roles - the entrepreneurial journalist is seen less as the odd-jobber working on commission and more of a business partner.
\end{abstract}

KEYWORDS: freelance journalism, entrepreneurial journalism, labor market, newsrooms, news production, precarity.

\section{INTRODUCTION}

For more than two decades, news organizations around the world are increasingly more open to cooperation with non-standard workers outside organizational employment. The definition of freelance journalists has diverged for many reasons (Briggs, 2012; Deuze, 2009; Deuze \& Witschge, 2018, 2020). On the one hand, news organizations have increasingly outsourced content production due to decreasing revenues and changing labor markets (Edstrom \& Ladendorf, 2012; 
Gollmitzer, 2019; Rosenkranz, 2019). On the other hand, to meet the demand for novel and divergent skills news organizations use non-journalistic actors (e.g., fact-checkers initiatives, data activists, start-up specialists, etc.) in the peripheral areas of journalism (Cheruiyot \& Ferrer-Conill, 2018; Kuś \& Barczyszyn-Madziarz, 2020). While the newsrooms may be optimizing labor costs and "buying" skills from actors outside the journalistic field, the providers of these services (e.g., freelancers or entrepreneurial journalists) must possess a variety of other skills from marketing and business management (Briggs, 2012). Providing content for journalism and public relations' conflicting roles stems from the controversy between the journalistic entrepreneur and the journalistic idealist (Mathisen, 2017; 2019). However, news organizations can also be unwelcome (Örnebring, 2016) and may lead to a deficit of trust towards freelancers.

While studies on European examples of freelancers and journalistic start-ups have shown a variety of opportunities that entrepreneurial journalism provides (e.g., Deuze \& Witschge, 2020), there are downsides to it. Cohen et al. (2019) analyzed the situation after the corporate restructuring in Canadian media and found that many journalists moved from secure full-time positions to precarious employment status, including freelancing in journalism and other fields. Örnebring (2018) described the same phenomenon - the competition over newsrooms as customers and the financial crisis's influence impacted the freelance remuneration rates and made this way of working financially precarious. It is possible to predict or even prevent that sort of outcome by monitoring change in the journalistic field, which is where researchers' contributions are beneficial. A freelancer profile is much more complex than it used to be and differs by a country's journalistic culture. Therefore, it is vital to investigate how freelancers' primary partners - the news organizations - perceive their role and collaboration opportunities.

This study outlines the change in Estonian newsroom editors' perspectives towards freelance journalists. The objective is to see how the possible change in defining non-standard and outsourced journalistic work may influence the news organization's cooperation with freelancers. A supplementary objective was to explore how the Covid-19 crisis affected the freelancers. The present study also initiates a discussion on how employment regimes influence journalistic labor markets and challenge research on precarity in journalism by arguing that changes in the journalistic labor market may not always result in precarity. 


\section{RESEARCH ON FREELANCE JOURNALISM}

Media researchers have repeatedly pointed out the changing profile of freelance journalists. Cock and Smaele (2016), for example suggest the reasons for any profile change differ in each country and are due to journalists' conscious decisions, promoted by technological, entrepreneurial, and societal change. More commonly, research acknowledges the journalism profession is increasingly becoming more precarious with decreasing resources and redundancies in the newsrooms driving the change (Briggs, 2012; Deuze, 2009; Örnebring, 2016, 2018). The transformation from being fully employed to self-employment shows that freelance journalists are neither employees nor free professions. While freelancers can be used as gap-fillers in the conditions of newsrooms' diminishing resources, they may also function as innovators in audience participation (Holton, 2016: 925). This accords with Deuze and Witschge $(2017,2020)$ who found that entrepreneurial journalism is both a way to make a living as an independent journalist and an opportunity for journalism as a profession to renew itself.

The divergent palette of journalistic skills and competencies enables freelancers to fulfill roles in many other fields bordering news media. The interrole conflicts were also experienced by multimedia production freelancers who worked for international non-governmental organizations and whose content was pitched to mainstream news organizations (Wright, 2016). Freelance journalists often hold secondary employment in public relations (PR), which leads to conflicting self-concepts in fulfilling the two roles (Fröhlich et al., 2013; Örnebring, 2016). While fulfilling controversial roles, they are also entrepreneurs, which is an additional role with its financial aims. The conflicting roles are best described by Mathisen (2017), who divides freelancers into entrepreneurs and idealists. The idealists may accept low income if they have opportunities to work with journalism they deem important; the entrepreneurs are driven by succeeding in their own business and refer to partnering news organizations as customers (Mathisen, 2019). Successful freelance journalists have broad social networks or partners who provide professional support regarding journalism, but they also use help in accounting and budgeting since "running a business" takes an integral part of their time and adds up to having a second job (Cock \& Smaele, 2016; Hunter, 2015). Therefore, freelancers must possess skills and competencies beyond the journalistic field. As the previous overview demonstrates, most research on freelance journalism is based on self-employed or entrepreneurial journalists. There is a gap in the studies on the partnering side - the news organizations on which freelance journalists mostly depend. 


\section{EMPLOYMENT REGIMES AND PRECARITY}

Studies on changes in the labor market have often concluded that externalizing news production transfers organizational risks over to the freelancer (see Norbäck \& Styhre, 2019), freelance and entrepreneurial journalists experience intense income insecurity (Gollmitzer, 2019), and changed working conditions lead to overall precarity that prohibits journalism's institutional functioning (Hayes \& Silke, 2019). The issue of freelancers' work conditions, financial vulnerability, and various rights restrictions is not new in journalism studies (see Baines \& Kennedy, 2010). The changes in occupational norms and practices accompanied by non-standard employment situations and the growing precarity has been in progress for at least two decades. As Örnebring (2018) outlines, the literature on precarity is based on the sociology of work and is rich in theory but is empirically speculative. The changes in the journalistic labor market vary by country and differ in reasons. Therefore, it would be wise to address the changes through a more comprehensive concept of employment regimes.

One component of the employment regime is related to the labor market's economic dimension as types and forms of contracts. Changes in contract-regimes are crucial for the externalization of production. According to Rosenkranz (2019: 617), the three dimensions of contracts as social relations refer to: 1) devices for conducting an exchange, they set the conditions for economic interaction, reduce uncertainty, and structure markets; 2) temporal scripts of the interactions that frame the mutual obligations and restrictions through time; 3) symbols of community with a function in the societal order of lean capitalism and of occupational norms in particular. These dimensions are useful assets in analyzing the change in the journalistic labor market. Another component of the employment regime relates to innovation and skills. Newsrooms often outsource production for skills and competencies to promote innovation. However, if the newsroom cannot absorb and integrate the novel skills and competencies, the outsourced innovation cannot be considered successful (Örnebring \& Ferrer-Conill, 2016). This, in a broader context, relates to journalism training and education, tightly connected to how news organizations value outsourced content.

Gollmitzer (2019) and Cohen et al., (2019) are relatively critical about the unpaid element of content production that freelance journalists provide since newsrooms pay for finished products and not for work done in back-stage reporting processes. The final product price is negotiated between the news organization and its business partner - the entrepreneurial journalist. Therefore the development of the price of a journalistic product is also part of the entrepreneurial journalist's work. The price of the content is often related to its innovation in the production process. Several additional factors influence freelancers' 
working conditions from the labor market aspect, but some reasons stem from the personal choices of journalists as well. As Edstrom and Ladendorf (2012: 719) reveal, the freelance lifestyle offers a higher degree of self-realization, and often this way of working provides the opportunity for assignments with more depth and analysis than employed work. By bringing out this selection of components of employment regimes, we draw attention to the idea that all these components play a role in the context of this study, but certainly are not complete and should be taken into account while studying changes in the occupation forms in the journalistic labor market.

Returning to precarity, drawing from its contemporary studies, it is an inevitable part of the media market's development. Precarity is a manifestation of the finances of news organizations as they descend from the hugely profitable peaks of the 1970s and 1980s. Precarity can be interpreted as transforming from profitable business and occupational models to novel (and not yet invented) business models and hybrid forms of employment. It may be the inevitable future of journalism and outcomes diverge when studied in various media markets and environments.

\section{FREELANCERS IN THE MEDIA}

Belgium and the Netherlands are the two most notable examples where freelance journalists bolster the journalistic labor market. In Belgium, every fifth journalist is a freelancer (Raeymaeckers et al., 2013). This statistic refers to a significant part of the institution which cannot be called atypical (De Cock \& de Smaele, 2016). In Estonia, the overall number of people engaged in the media industry is 4500 (Kõuts-Klemm et al., 2019); approximately 1000 are directly occupied as professional journalists in news organizations (Krusell \& Pihl, 2019). According to the Worlds of Journalism research data, 1.5 percent of all Estonian journalists reported being occupied as freelancers (Josephi et al., 2019). Since the "Worlds of Journalism" data was collected in 2014 and embraced only news organizations, it does not fully cover the diverse body of freelance journalists in the media industry.

Every media market has its peculiarities and deserves to be researched to incorporate freelance journalists in its specific cultural aspect. While in most Western countries, the proportion of freelancers is around 20 to 30 percent, in Germany, similarly to Estonia, the relatively small freelance community is increasingly contracted as small entrepreneurs (Meyen \& Springer, 2008). Research shows that highly developed media markets have experienced a higher percentage of journalists working as freelancers. The precarity of labor market changes is experienced differently depending on union membership, contractual 
regimes, historical and educational background (Josephi et al., 2019). Though the rapid change towards freelancing is in many countries related to the concept of precarity (Hayes \& Silke, 2019; Matthews \& Onyemaobi, 2020), studies have also shown that employment regimes play a substantial role in the development of freelancers' community and experiencing precarity (Gollmitzer, 2019; Massey \& Elmore, 2018; Salamon, 2020).

Our study is based on the Estonian media market, serving a population of 1.3 million Estonian-speaking people. However, its employment regimes are comparable with many other small Post-Soviet journalism environments in Central and Eastern Europe. Estonia resembles Scandinavian journalism environments with its relatively weak influences from political, economic, and organizational domains (Hanitzsch et al., 2019). This leads us to the objective of this study. We outline the change in editors' attitudes towards freelance journalists over a five year period. Stemming from this aim, we propose the following research questions: (RQ1) How has the perception of freelance journalists changed among editors-in-chief? (RQ2) How has the news organizations' partnership with freelance journalists changed? (RQ3) How did the Covid-19 crisis influence news organizations' partnerships with freelancers? The beginning of 2020 brought the unexpected conditions of the Covid-19 pandemic. This provided journalists, news organizations, and academics novel prospects. We used the opportunity to ask three additional questions from the editors in October 2020. The questions were: (RQ4) Did the Covid-19 pandemic condition any change regarding the newsroom's cooperation with freelancers? (RQ5) What did these changes contain? (RQ6) What sort of content would they outsource to freelancers under pandemic conditions?

To achieve the study goals, we interviewed managers or editors-in-chief of seven newsrooms in 2014 and repeated the interviews with people in the same managerial positions five years later. Regardless of the precise job title, we use the term 'editor' to refer to the editor-in-chief or newsroom manager position because all of our respondents were in the same positional level.

\section{METHODOLOGY}

In this study, we conducted semi-structured interviews, twice each with seven editors in 2014 and 2019. Our selection consisted of three magazines (lifestyle magazines Eesti Naine and Pere ja Kodu; popular science magazine Horisont), two newspapers (the daily newspaper Postimees; the weekly newspaper Maaleht), a radio news program (Estonian Public Broadcaster, ERR), and commercial television news (TV3 Seitsmesed). Except for the editor of Postimees, the set of editors asked about the influence of Covid-19 was the same set as in 2019, making the 
second set comparable to the first set of interviews. The relatively small sample of interviews $(\mathrm{N}=14 ; \mathrm{n}=7, \mathrm{n}=7)$ can be questioned in qualitative terms for not providing an overview of the whole field. We justify our sample with two arguments. Firstly, the country-specific circumstances need to be taken into consideration. Estonia is a small media market: the population is 1.3 million, and the media market is divided between three large media organizations and a couple of smaller independent ones. Secondly, the newsrooms were selected using preclusion. Our background work showed that newsrooms that cover general newsbeat do not outsource content production to freelance journalists due to the work's timely nature.

For this reason, all general newsbeat and online newsrooms were excluded. Then, all newsrooms that had not outsourced journalistic content production for the past five years, and stated that they did not consider doing so, were also excluded. This revealed the seven newsrooms included in our sample. Drawn from these circumstances, our sample is relatively concise but comprehensive, as it represents most of the newsrooms across the various media organizations that outsource content production to freelance journalists. All the interviews lasted approximately 30 minutes. They were audio-recorded and then transcribed. In the first set of questions, editors were asked to describe how they see freelance journalists, and why. The second set of questions focused on the practices and conditions under which they use freelancers' services in their newsrooms.

The transcripts of interviews were analyzed using data coding (Charmaz, 2006; Ritchie \& Spencer, 2002). We used the initial set of codes that stemmed from this study's research questions and on the literature in the first two rounds of interviews. The codes for analyzing the transcripts can be divided into three sets. The first set focused on defining a freelance journalist to compare how editors profile freelance journalists and how this has changed over time (RQ1). The second set of codes marked editors' descriptions of ongoing co-operations and expectations on freelancers' content (RQ2). In the repetitive reading of transcripts, we decided to add the code 'obstacle', which define freelancers and describe the partnership started, to stand out as an essential factor related to several aspects of employment regimes. In October of 2020, we conducted the additional interviews with the editors to elaborate as to how the Covid-19 crisis influenced cooperation with freelancers (RQ3). The transcripts were analyzed using the second set of codes.

The transcripts were indexed by comparing the highlighted quotes of interviewees. The quotes were charted by extracting them and rearranging them into appropriate thematic content. Two coders coded all transcripts using MaxQDA. The minimum overlap threshold between coded segments of the first two sets of interviews was $70 \%$. The overlap threshold refers to coders' accuracy highlighting the same segment in MaxQDA when applying a given code. The 
additional questions regarding the Covid-19 crisis were coded and analyzed with qualitative analysis software Nvivo by one coder.

The nature of this study does not enable the respondents to be anonymous; therefore, all interviewees were asked for permission to be on-the-record and identifiable. Since, in this article, their position, rather than their name, is relevant, we have referred to them by their title. We collected the data on the interviewees' socio-demographic or professional experience as part of the preliminary selection process. All have worked in journalism for more than 12 years, many of them in the same or similar ranking position; with one female exception, all are men in their $40 \mathrm{~s}$ or $50 \mathrm{~s}$. In the analysis and interpretation phase, it became evident that editors in their professional position represent the organizational mechanisms, and their socio-economic status and professional background may have posed only modest influence on their editorial and managerial decisions.

\section{FINDINGS}

To use a freelance journalist's services, the newsroom manager initially has to acquire a managerial perception of freelancers and the type of journalistic content they provide. Also, the managerial decision to do so depends on multiple factors, e.g., developments of technology and changes in the overall labor market.

The first set of interviews of this study took place in 2014, six years after the start of the 2008 economic recession. Though the economy showed signs of overall stabilization and even growth, this did not reach the media market. This was conditioned by the growing influence of digital intermediaries like Google, Facebook, and YouTube that hindered the restoration of the advertising capacity and revenue (Himma-Kadakas, 2018, pp. 20-22). In the first set, our interviewees emphasized that by 2014 newsrooms had adjusted to having the decreased workforce of the recession, and the labor market was flooded with freelancers who had been made redundant from newsrooms. On the one hand, the economic pressure partly preset the conditions for having freelance journalists in the market. On the other hand, the perception of a freelancer was primarily shaped by the notion of an unemployed journalist or a casual worker, and the changes in the labor market had reinforced this understanding.

The widespread understanding of a freelancer in Estonia is that it is a person who has not found a job. The overall freelance culture in Estonia has not been developed. I have studied and worked in Germany, and things are quite the opposite there. [Editor of Postimees, 2014] 
The freelancer-market consists of unemployed journalists or those who send their stories just to get published anywhere. It is a landing pad for redundant journalists. [Editor of Pere ja Kodu, 2014]

The interviews conducted in 2014 revealed that the interviewees often described obstacles that hindered the collaboration between the newsroom and the freelancer. Therefore we also decided to use the term 'obstacle' to outline the perception of freelance journalists and how the partnership has changed stemming from them. Five main obstacles stand out from the interviews.

The first was separation from the newsroom members, which did not allow the freelancer to adjust and conform to the practices and stylistic specifics of the content. The editors of newspapers were especially concerned about the 'newspaper losing face' if freelance journalists used unconventional approaches or stylistic practices in stories. The exception was the editor of the women's lifestyle magazine Eesti Naine who explained that using freelancers enabled her to diversify the content with the individual variance of the specific author and the divergence from the magazine's main style.

The second obstacle, pointed out mainly by the managers of television and radio newsrooms was the lack of technical resources to provide high-quality content. Both television and radio newsrooms had experiences of outsourcing journalistic content from freelancers. The commercial television newsroom had developed regular cooperation with freelance journalists and had provided them with the technology to accomplish the quality standards. The public service radio newsroom had discarded collaboration with freelancers a couple of years earlier due to their inability to ensure the necessary technical quality; according to the newsroom manager, in 2014, there were not any sufficiently technically multi-skilled and professional freelance journalists in Estonia.

In our case, the main obstacle is the lack of freelance service providers. We would outsource more if more freelance journalists could provide quality. [Editor of ERR radio news, 2019]

By 2019, the radio newsroom was the only one that still reflected the lack of freelancers' adequate technical skills. Other interviewees expressed satisfaction with the technical abilities to partner freelance journalists and showed readiness to outsource more multi-platform and multimedia content. The advancement of technical skills can also be explained by the increased availability of affordable technical resources (e.g., cameras, recorders, editing, data analysis software, etc.). This enabled the technology-savvy journalists, data activists, and multimedia enthusiasts to diversify their palette of skills and offer services and stories that the newsrooms were ready to outsource. 
The third obstacle referred to the deficiency of in-depth knowledge of a specific field, often outside journalism. For example, the editor of the popular science magazine Horisont stated in both interviews that the magazine was unable to use freelancers since they could not find a journalist who would know a specific field of science. The same was indicated by newspaper editors who expected expert knowledge to be packaged as technically converged with multimedia-rich storytelling. The interviewees expressed readiness to outsource investigative journalism and data journalism projects that require specific knowledge and highly-skilled teamwork, which would otherwise be costly for the newsroom to produce with their full-time workforce. As (Kõuts-Klemm, 2019) showed, newsrooms lack data literacy skills and journalists' criticism of sociological data is weak, knowledge of statistical methods and principles is scarce, and journalists lack skills for data collection and analysis. This explains newsrooms' demands to outsource this sort of project to data activists or other partners who can combine this skill practice with journalistic content production.

The fourth obstacle revealed by all the editors was the reluctance to accept content from freelancers who may simultaneously be in both journalism and PR. As Örnebring (2016) showed in his comparative study, Estonia is a rare exception where the mixing journalism and PR roles is not accepted in newsrooms. Integrating or mixing these roles made the interviewees cautious and mistrustful towards hiring freelancers. One of the editors described a situation that deepened this mistrust:

There is a group of PR people who act as freelance journalists, but they do not even say that they are actually working for some company, or for example, representing an artist. She just does not say, to which other newsrooms she has also offered a similar story. [Editor of Eesti Naine, 2014]

In 2019, the interviewees did not describe this sort of experiences or fears. This does not necessarily mean that those doubts do not exist. However, one possible explanation during the five year interval there was a rearrangement and settling of the journalistic labor market regarding freelance and entrepreneurial journalism, which the interviews reflect. In 2019 the commitments, responsibilities, and restrictions were usually regulated in the contracts between the media organizations and the freelancers' enterprises. These agreements were also closely related to the solutions behind overcoming the fifth obstacle.

The fifth obstacle concerned the competition between media organizations. The request for exclusiveness, described in the previous obstacle, is the focal point of why newsrooms would like to 'own' or have freelancers work solely for them. 
Some of the freelancers are also private entrepreneurs who give us an invoice for their articles, but at the same time, they are full - or part-time employed in some other newsroom. [Editor of Maaleht, 2014]

Simultaneously, this pursuit of exclusiveness also steered the development of freelance 'odd-jobbers' to entrepreneurial journalists. In the 2019 interviews, editors appreciated the value of the entrepreneurial contract with a small production company that can also be called a journalistic venture or a start-up. This assures stability for the news organization and guarantees a stable income for the journalist.

I prefer to have concrete contractual relations with freelance partners. This enables me to influence which competitive media houses he works for, but of course, I cannot always afford this since the partner also expects a certain level of income. So, the freelance partner is entitled to provide services also for our competitors. [Editor of $\mathrm{TV}_{3}$ newscast, 2019]

Comparing the two sets of interview indicates the clarification of the role freelance journalists and the development of entrepreneurial relations with news organizations. This refers to the direction, which accords with the distinction outlined by Baines and Kennedy (2010), and enables us to conclude that Estonian freelance journalists are more entrepreneurial (perceived as having a sense of independence, empowerment, and self-direction) than self-employed (insecure, powerless, dependent on newsrooms). Hence, being a freelance journalist demands skills outside journalistic core competencies, such as an entrepreneurial knowledge of finance and accounting, a juridical knowledge of business interactions, marketing, client relations, etc.

All the obstacles reflected by the interviewees in 2014 were preconditioned by the notion that freelance journalists did not provide the service that the newsroom demanded. Instead, freelancers offered content of their preference, which did not always meet the needs of the newsroom. Except for radio news, all other editors had reassessed this notion by 2019. The change is evident in newsrooms perceiving freelance journalists as entrepreneurial partners who provide certain journalistic content for the newsroom under prearranged agreements. It is accurate to prefer the term entrepreneurial journalist to the term freelancer. The outsourced content can be regular (e.g., monthly articles and photos for a magazine; daily video stories for the television) or project-based (e.g., stories that require investigative work, data analysis and visualization, multimedia content, fact-checking initiatives, etc.). The content is outsourced because newsrooms may lack the specific competence to produce these stories or for the objective to economize costs on a permanent full-time workforce. 


\section{IMPACT OF COVID-19 PANDEMIC}

In our sample, the newspapers and magazine editors generally stated that the Covid-19 pandemic did not greatly change their cooperation with entrepreneurial journalists. However, the detailed picture is more diverse. The editors of the weekly newspaper Maaleht, the women's lifestyle magazine Pere ja Kodu, and the popular science magazine Horisont said their usual content production has entirely or in specific topical fields been outsourced. Hence, the crisis did not substantially affect their cooperation with external authors regarding subject matter due to content production routines.

The editors of newspapers and the radio news program admitted that the contracts with entrepreneurial journalists were negotiated at the very beginning of the pandemic, and in some cases, fees were temporarily lowered. Nevertheless, the editors prioritized keeping the contracts and the co-operations with the network of external authors. By fall 2020, when the effects were estimable, the co-operations mostly recovered on the pre-crisis level. The Covid-19 pandemic offered a case study for the nature of contractual regimes in the journalistic labor market. Our interviews with editors showed that the contracts' negotiability aspect enabled both partners to temporarily change the economic interactions but did not terminate them. The editors' inclinations towards preserving contractual relations with entrepreneurial journalists gives evidence of functioning occupational roles between the news organizations and the entrepreneurial journalists' community.

The newspapers, radio, and television editors mentioned a change in the need for specific Covid-19 coverages from external authors from local regions in Estonia and other countries abroad. This sort of the change in demand was understandable as travel restrictions prevented news organizations from sending their journalists to report from the spot. The co-operations concerned mainly news coverage and were temporarily activated during the most critical time of the pandemic. The news organizations keep a network of external authors that are used in specific circumstances.

The answers to the question of what content the editors would outsource to freelancers in current conditions gave notable results. Regardless of their platform, the editors expressed the expectation for more topically diverse and technically high-quality content:

First and foremost, I would like the news to have a hyper-local view on topics. This concerns both authors in Estonia and abroad. The recording equipment has reached the level where it is possible to get a technically high-quality outcome, and the author does not need to make significant investments. This 
enables us to widen the network of external authors. [Editor of ERR radio news, 2020]

As can be concluded from both sets of interviews, the main criterion for seeking or terminating cooperation with entrepreneurial journalists is the content's professional quality. The editor of the magazine Eesti Naine expressed the expectation for professionally produced diverse multimedia content, the flexibility in adjusting to timely topics, and the ability to address the magazine's target audience. This refers to the potential for development in product and service design on the entrepreneurial journalists' side.

\section{CONCLUSIONS}

This study explored the change of Estonian media organizations' perception of freelance journalists over five years (2014 to 2019) and detected a readiness to cooperate with freelance and entrepreneurial journalists. The findings were additionally tested in the conditions of the Covid-19 pandemic in 2020. The interviews' results confirm that the editors' perception of who freelance journalists are has changed, and the main difference reflects in the newsrooms' approach to employment regimes, especially contractual ones. While in 2014, managing editors saw freelancers as unemployed journalists who offered their articles for publication on commission, in 2019, the perception had shifted towards the concept of the entrepreneurial journalists (RQ1). The additional interviews during the Covid-19 pandemic in 2020 showed that the crisis did not change this perception, which consolidated the findings regarding the change (RQ2 and RQ3). The described changes resemble the characterization outlined by Baines and Kennedy (2010), where the journalist is a small-scale entrepreneur who provides co-operation with their news content organizations under-regulated partnership agreements (RQ2). These business-to-business agreements guarantee stability and certainty for both parties and minimize risks for news organizations (e.g., competition on exclusiveness, conflicts between journalistic and PR roles, as described by Örnebring, 2016).

We believe that it is insufficient to talk merely about changes in the journalistic labor market resulting in precarity. Instead, a more comprehensive concept of employment regimes should be addressed. The employment regime of a particular country's journalistic labor market may substantially impact how the change is perceived and what consequences it poses on the profession. Our study did not set the objective of exploring either of both the employment regime, and the precarity in the Estonian journalistic labor market. However, the results of our interviews and the monitoring reports (Josephi et al., 2019; 
Krusell \& Pihl, 2019) on Estonian journalists do not indicate any processes leading to an increase in precarity, as several studies in other countries have shown (e.g., Hayes \& Silke, 2019; Matthews \& Onyemaobi, 2020; Norbäck \& Styhre, 2019). In Estonia, but also in many other countries of a similar journalistic culture, this may be conditioned by several factors such as the contractual regimes of the overall labor market, the state systems that support entrepreneurship, the tax system, the role of journalists' unions, the profession's openness to reporters outside journalistic training, and integration of entrepreneurial knowledge to higher education curricula. The employment regimes components deserve more detailed study and are worth considering in the studies focusing on journalists' precarity.

The newsrooms outsource journalistic content mainly for economic reasons and acquire specific knowledge, skills, and competencies, which would otherwise be too costly to keep as in-house knowledge. In this sense, our study supports the conclusions Holton (2016) reached: newsrooms rely on freelancers to override journalistic norms in ways that can enhance news work, and using atypical employment forms may breathe new life into news organization business models. Journalistic content production has emerged from the conventional borders. Data activists and fact-checking organizations are just non-journalistic actors working on the periphery of journalism. Nevertheless, although fact-checkers may not see themselves as journalists or even distance themselves from that role, the core of their actions resemble journalistic fact-checking, and they often collaborate with newsrooms (Cheruiyot \& Ferrer-Conill, 2018). Kuś and Barczyszyn-Madziarz (2020) reached a similar result stating that factchecking initiatives in Poland strongly influence promoting media literacy. The development of the freelancers' position in the media market positively affects the whole journalistic field. As Holton (2016) concludes, newsroom editors take lessons from freelancers and set them as examples for newsroom journalists; this, in the long run, may also turn out to be a source of innovation. The same applies to data analysis and storytelling. As Kõuts-Klemm (2019) showed, journalists have neither the knowledge for data literacy at the fact-checking level, nor do they possess rigorous data analysis and storytelling skills. Newsrooms can outsource complex skills and competencies. Here the journalistic entrepreneurs (e.g., initiatives of investigative or data journalism and fact-checkers) can help fulfill this need. Nevertheless, newsrooms need to comprehend that outsourcing skills under the flag of innovation can be deceptive if the newsroom itself does not adopt the changes. This result was partly addressed by Örnebring and Ferrer-Conill (2016) but deserves further research.

Estonia's media market shows clear signs of adopting diverse collaborative forms that make the journalistic field more divergent. The freelancer's concept has changed, indicating strong integration between journalistic and entrepreneurial 
roles. As our results show, newsrooms are open to collaborations with freelancers or entrepreneurial journalists who provide investigative or other resource-intensive content (RQ2). This, under normal circumstances, does not apply to news content but is acceptable in longer and timeless formats (e.g., investigative or feature stories in magazines). However, during the crisis of the Covid-19 pandemic, the editors became more open to cooperation for news content. Editors expect freelancers to be proactive and offer multimedia-rich productions that require journalistic multiskilling (RQ2 and RQ3). This article offers reassuring signals to journalists who consider becoming entrepreneurs, as the Estonian news organizations' employment regimes show welcoming signs. For media educators, the article presents a challenge for developing curricula that fulfill the demands of the altered employment regimes.

\section{ACKNOWLEDGEMENTS}

This research was partly supported by the Ander Foundation: Anne Marie och Gustaf Anders Stiftelse för mediaforskning.

\section{REFERENCES}

Baines, D., \& Kennedy, C. (2010). An Education for Independence, Journalism Practice, 4(1): 97-113. Briggs, M. (2012). Entrepreneurial Journalism: How to Build What's Next for News. CQ Press.

Charmaz, K. (2006). Constructing Grounded Theory: A Practical Guide Through Qualitative Analysis. In: K. Charmaz (ed.), Introducing Qualitative Methods (Vol. 1). SAGE Publications Ltd.

Cheruiyot, D., \& Ferrer-Conill, R. (2018). "Fact-Checking Africa." Digital Journalism, 6(8): 964-975.

Cock, R. D., \& Smaele, H. de. (2016). Freelancing in Flemish News Media and Entrepreneurial Skills as Pivotal Elements in Job Satisfaction. Journalism Practice, 10(2): 251-265.

Cohen, N. S., Hunter, A., \& O’Donnell, P. (2019). Bearing the Burden of Corporate Restructuring: Job Loss and Precarious Employment in Canadian Journalism. Journalism Practice, 13(7): 817-833.

Deuze, M. (2009). The people formerly known as the employers. Journalism, 10(3): 315-318.

Deuze, M., \& Witschge, T. (2017). Beyond journalism: Theorizing the transformation of journalism. Journalism, 19:165-181.

Deuze, M., \& Witschge, T. (2018). Beyond journalism: Theorizing the transformation of journalism. Journalism, 19(2): 165-181.

Deuze, M., \& Witschge, T. (2020). Beyond Journalism. Wiley.

Edstrom, M., \& Ladendorf, M. (2012). Freelance Journalists as a Flexible Workforce in Media Industries. Journalism Practice, 6(5-6): 711-721. 
Fröhlich, R., Koch, T., \& Obermaier, M. (2013). What's the harm in moonlighting? A qualitative survey on the role conflicts of freelance journalists with secondary employment in the field of PR. Media, Culture \& Society, 35(7): 809-829.

Gollmitzer, M. (2019). Employment Conditions in Journalism. In Oxford Research Encyclopedia of Communication. Oxford University Press.

Hanitzsch, T., Ramaprasad, J., Arroyave, J., Berganza, R., Hermans, L., Hovden, J. F., Láb, F., Lauerer, C., Tejkalová, A., \& Vos, T. P. (2019). 5. Perceived Influences: Journalists' Awareness of Pressures on Their Work. Columbia University Press.

Hayes, K., \& Silke, H. (2019). Narrowing the discourse? Growing precarity in freelance journalism and its effect on the construction of news discourse. Critical Discourse Studies, 16(3): 363-379.

Himma-Kadakas, M. (2018). Skill performance of Estonian online journalists: Assessment model for newsrooms and research [Thesis]. Retrieved February 21, 2021 from https://dspace.ut.ee/handle/10062/59824.

Holton, A. E. (2016). Intrapreneurial Informants. Journalism Practice, 10(7): 917-927.

Hunter, A. (2015). Crowdfunding independent and freelance journalism: Negotiating journalistic norms of autonomy and objectivity. New Media \& Society, 17(2): 272-288.

Josephi, B., Hanusch, F., Alonso, M. O., Shapiro, I., Andresen, K., Beer, A. de, Hoxha, A., Moreira, S. V., Rafter, K., Skjerdal, T., Splendore, S., \& Tandoc, E. C. (2019). 4. Profiles of Journalists: Demographic and Employment Patterns. Columbia University Press.

Kõuts-Klemm, R. (2019). Data literacy among journalists: A skills-assessment based approach. Central European Journal of Communication, 12(3): 299-315.

Kõuts-Klemm, R., Harro-Loit, H., Ibrus, I., Ivask, S., Juurik, M., Jõesaar, A., Järvekülg, M., Kauber, S., \& Koorberg, V. (2019). Meediapoliitika olukorra ja arengusuundade uuring. [Report on media policy's state of art and development]. Tartu Ülikooli ühiskonnateaduste instituut. Retrieved September 30, 2020 from https://www.digar.ee/arhiiv/et/raamatud/121682.

Krusell, S., \& Pihl, K. (2019). Tulevikuvaade tööjõu - ja oskuste vajadusele-Kultuur ja loometegevus: Audiovisuaalvaldkond, sõna ja keel, turundus ja kommunikatsioon, disain ja kunst, trükitööstus [OSKA study of film and video, art and design, journalism, content creation and language, marketing and communications and printing occupations]. SA Kutsekoda, tööjõuvajaduse seire - ja prognoosisüsteem OSKA. Retrieved September 20, 2020 from https://oska.kutsekoda.ee/wp-content/ uploads/2017/10/Uuringuaruanne_-kultuur-ja-loometegevus_-2.pdf.

Kuś, M., \& Barczyszyn-Madziarz, P. (2020). Fact-checking initiatives as promoters of media and information literacy: The case of Poland. Central European Journal of Communication, 13(2): 249-265.

Massey, B. L., \& Elmore, C. (2018). Freelancing in Journalism. In Oxford Research Encyclopedia of Communication. Oxford University Press.

Mathisen, B. R. (2017). Entrepreneurs and Idealists: Freelance journalists at the intersection of autonomy and constraints. Journalism Practice, 11(7): 909-924.

Mathisen, B. R. (2019). Ethical Boundaries among Freelance Journalists. Journalism Practice, 13(6): 639-656.

Matthews, J., \& Onyemaobi, K. (2020). Precarious Professionalism: Journalism and the Fragility of Professional Practice in the Global South. Journalism Studies, 21(13): 1836-1851. 
Meyen, M., \& Springer, N. (2008). Freie Journalisten in Deutschland (p. 22). Retrieved February 17, 2021 from https://www.zvab.com/9783867641562/Freie-Journalisten-Deutschland-Report-Michael-3867641560/plp.

Norbäck, M., \& Styhre, A. (2019). Making it work in free agent work: The coping practices of Swedish freelance journalists. Scandinavian Journal of Management, 35(4): 101076.

Örnebring, H. (2016). Journalists, PR professionals and the practice of paid news in Central and Eastern Europe: An overview. Central European Journal of Communication, 9(1): 5-19.

Örnebring, H. (2018). Journalists thinking about precarity: Making sense of the \&quot;new normal\&quot; \# ISOJ Journal, 8(1): 109-127.

Örnebring, H., \& Ferrer-Conill, R. (2016). 14 Outsourcing Newswork. In: T. Witschge, C. W. Anderson, D. Domingo \& A. Hermida (eds.), The SAGE Handbook of Digital Journalism (pp. 207-221). London: SAGE Publications Ltd.

Ritchie, J., \& Spencer, L. (2002). Qualitative Data Analysis for Applied Policy Research. In: A. Huberman \& M. Miles (eds.), The Qualitative Researcher's Companion. London: SAGE Publications, Inc.

Rosenkranz, T. (2019). From Contract to Speculation: New Relations of Work and Production in Freelance Travel Journalism. Work, Employment and Society, 33(4): 613-630.

Salamon, E. (2020). Digitizing freelance media labor: A class of workers negotiates entrepreneurialism and activism. New Media \& Society, 22(1): 105-122.

Wright, K. (2016). “These Grey Areas.” Journalism Studies, 17(8), 989-1009. 